\title{
Peritonsillar Abscess
}

National Cancer Institute

\section{Source}

National Cancer Institute. Peritonsillar Abscess. NCI Thesaurus. Code C128322.

An abscess that develops in the space surrounding one or both palatine tonsils. 